\title{
Türkiye'de 1924-2012 Yılları Arası Genel Bütçe Gelir ve Gider Tahminlerinin Doğruluğunun Değerlendirilmesi
}

Sibel ÖZCAN ${ }^{*}$

\author{
Geliş Tarihi (Received): 05.04.2017 - Kabul Tarihi (Accepted): 29.05.2017
}

\section{Öz}

Bu çalışmada 1924-2015 dönemi için Maliye Bakanlığı tarafından hazırlanan genel bütçe gelir ve harcama tahminlerinin doğruluğu; bütçe ilkelerinden doğruluk ve samimiyet ilkeleri göz önünde bulundurularak incelenmiştir. Bu amaçla çalışmanın ilk bölümde Türkiye'deki bütçeleme sürecine ve literatür taramasına yer verilmiştir. Ardından değerlendirme yöntemleri tanıtılmış ve tahmin hatası, Theil'in eşitsizlik katsayısı ve rasyonel beklentiler hipotezi kullanılarak tahminlerin doğruluğu analiz edilmiştir. Analizlerde, söz konusu dönem içerisinde farklı bütçeleme sistemlerinin geçerli olması nedeniyle her bir bütçeleme sisteminin uygulandığı dönem ayrı olarak ele alınmıştır. Sonuç olarak gelir ve başlangıç ödeneklerinin düşük, yılsonu ödeneklerinin ise yüksek tahmin edildiğini görülmüştür. İlave olarak yılsonu ödenek tahmininde, başlangıç ve gelir tahminine kıyasla daha başarılı olunduğu ve genel olarak zaman içerisinde tahminlerde bir iyileşme olduğu tespit edilmiştir. Rasyonel beklenti hipotezi sonucuna göre ise ne gelir ne de harcama tahminlerinin rasyonel olarak yapılmadı̆̆ görülmüştür.

Anahtar Kelimeler: Bütçe, Kamu Harcaması, Tahmin hatası, Theil'ın eşitsizlik katsayısı, Rasyonel beklentiler

\footnotetext{
* Arş. Gör., Hacettepe Üniversitesi, İktisadi ve İdari Bilimler Fakültesi, Maliye Bölümü, sibel.ozcan @ hacettepe.edu.tr. Bu çalışma, yazarın Hacettepe Üniversitesi Sosyal Bilimler Enstitüsü tarafından 2012 yılında kabul edilen "Genel Bütçe Gelir ve Harcama Tahminlerinin Analizi: Türkiye Üzerine Ekonometrik Bir İnceleme” başlıklı Yüksek Lisans Tezi temel alınarak hazırlanmıştır.
} 


\title{
The Analysis Of The General Budget Revenue And Expenditure Forecasts Between 1924-2012: An Econometric Study On Turkey
}

\begin{abstract}
In this study, the accuracy of the general budget revenue and expenditure estimates, which are prepared by the Ministry of Finance,for the period 1924-2015 has been examined considering the budget principles of accuracy. For this purpose in the first part give place to the budgeting process in Turkey and literature review. After then, evaluation methods were introduced and the accuracy of estimates was analyzed using the prediction error, Theil's inequality coefficient, and the rational expectation hypothesis. Since different budgeting systems are in force during the period in question, in the analysis, the period in which each budgeting system is applied has been handled separately. As a result of these analyses, estimations of revenue and initial allowances are underforecasted while the final allowances are overforecasted. Additionally, the final estimation was found to be more succesful and in general the estimates improved over time. According to the rational expectation test results, neither the income nor the expenditure estimates are seen as rational.
\end{abstract}

Keywords: Budget, Public Expenditure, Forecast error, Theil's inequality coefficient, Rational Expectation 


\section{Giriş}

2005 y1lı itibariyle yürürlüğe giren 5018 sayılı Kamu Mali Yönetimi ve Kontrol Kanunu'nda bütçe “... Belirli bir dönemdeki gelir ve gider tahminleri ile bunların uygulanmasına ilişkin hususlarl gösteren ve usulüne uygun olarak yürürlüğe konulmuş..." belge olarak tanımlanmıştır. Bu tanımda da açıkça ifade edildiği üzere, bütçeler esas itibariyle bir sonraki sene gerçekleşmesi öngörülen harcamalar için yapılan tahminlerden oluşmaktadır.

1973 senesi itibariyle uygulanmaya başlanan Program bütçe sisteminde Kalkınma Planları, 2006 senesi itibariyle uygulanan Performans esaslı bütçeleme sisteminde ise Orta Vadeli Program, bütçelerin hazırlanması noktasında önem arz etmektedir. Günümüzde çok yıllı bütçeleme anlayışı ile Orta Vadeli Program ve Orta Vadeli Mali Plana uygun olarak, kurumlar tarafından hazırlanan sonraki yıla ait bütçe tekliflerinin yasalaşması ile mali yıl içerisinde bütçe kanununda yapılan değişikler ile sene sonunda kesin hesap kanunun görüşülmesi vasıtasıyla denetimi yasama organına aittir.

Belirlenen uzun vadeli hedeflere ulaşılması ile bütçenin maliye politikası aracı olarak işlerlik kazanması, büyük oranda kurumlar tarafından talep edilen ödeneklerin belirlenmiş olan hedeflere uygun olarak hazırlanmasına ve hazırlanmış planlara riayet edilmesine bağlıdır. Hazırlanan bütçeye ne derece riayet edildiği ise bütçe ilkeleri arasında yer alan doğruluk ve samimiyet ilkelerine ne derece uyulduğu ile doğrudan alakalıdır.

$\mathrm{Bu}$ çalışmada doğruluk ve samimiyet ilkelerine ne derece uyulduğu, başka bir ifade ile hazırlanan bütçeler ile gerçekleşen harcamalar arasındaki fark incelenmiştir. Bu amaçla, 19242015 dönemi içerisinde ortaya çıkan genel bütçe tahmin ve gerçekleşmeleri arasındaki fark, üç yöntemle değerlendirilmiştir. Bu yöntemlerden tahmin hatası ve eşitsizlik katsayıları, farklı bütçeleme sistemlerinin kullanıldı̆̆ı dönemler için ayrı olarak hesaplanırken, rasyonel beklentiler hipotezinin analizinde dönemin tamamı ele alınmıştır.

Çalışma, üç başlık altında ele alınmıştır. Çalışmanın birinci bölümünde doğruluk ve samimiyet ilkeleri açıklanmış ve literatürde yer alan çalışmalara yer verilmiştir. İkinci bölümde değerlendirmede kullanılan yöntemler açıklanmış ve sonraki bölümde de elde edilen sonuçlara yer verilmiştir. Çalışmaya dair genel bir değerlendirme ise sonuç bölümünde yer almaktadır.

\section{Bütçelemede Doğruluk İlkesi ve İlgili Literatür}

Uzun vadeli olarak belirlenen hedeflere ulaşmada bütçelerin içinde bulunulan şartlara uygun olarak hazırlanmasının önemi büyüktür. Bu nedenle yapılan bütçe tahminleri hem 
objektif hem de sübjektif açıdan ele alınmalıdır. Tahminlerin objektif olması ile kastedilen doğruluk ilkesi, sübjektif olması ile kastedilen ise samimiyet ilkesidir (Gürsoy, 1980, s. 146).

Objektiflik ile bağdaştırılan doğruluk ilkesi, bütçe tahminlerinin ilgili yılın şartlarına göre, fazla iyimserlik ya da kötümserliğe kapılmadan hazırlanmasını gerektirir (Edizdoğan ve Çetinkaya, 2010, s. 122-123). Sübjektiflik ile ilişkilendirilen samimiyet ilkesi ise, yapılan tahminlerin tahmini yapanın gerçek kanaati sonucunda oluşturulmasıdır (Gürsoy, 1980, s. 146). Sonuç olarak bir tahmin belgesi olan bütçede yer alan rakamların gerçekçi olarak belirlenememesi bütçenin doğruluk ve samimiyet ilkelerine zarar vermektedir (Coşkun, 2000, s. 44).

Bütçe ile belirlenen hedefler arasındaki ilişkinin önemli olması nedeniyle farklı ülkeler ve farklı dönemler için bütçe tahminlerinin doğruluğunu ele alan birçok çalışma yapılmıştır. Bu konuda yapılan çalışmalardan ilki Allan (1965)'a aittir. 1951-1963 dönemini kapsayan çalışmada gelir ve gider bütçesi tahmin ve gerçekleşme rakamları arasındaki fark incelenmiş ve gelir bütçesinin gider bütçesine kıyasla daha doğru olduğu sonucuna varılmıştır (Allan, 1965, s. 323-325). İngiltere için yapılan ve daha uzun bir dönemi (1951-1978) kapsayan bir diğer çalışmada ise Allan'ın çalışmasında kullandığı yönteme ilave olarak Theil'in eşitsizlik katsayıları da kullanılmış ve gelir tahminlerinde zaman içerisinde bir iyileşme, gider tahminlerinde ise bir kötüleşme olduğu tespit edilmiştir (Davis, 1980, s. 190-193).

Theil'in eşitsizlik katsayısının kullanıldığı ve Kanada için yapılan benzer bir çalışma, 1949-1968 dönemi için Auld (1970) tarafından yapılmış ve yapılan tahminlerin zaman içerisinde iyileştiği görülmüştür. İncelenen dönem içerisinde gider bütçesinin düşük; gelir bütçesinin ise yüksek tahmin edildiği tespit edilmiştir (Auld, 1970, s. 509-511).

Hindistan için konu ile ilgili olarak Asher (1978), Bhattacharya ve Kumari (1988) ve Chakraborty ve Sinha (2008) tarafindan yapılan çalışmalar mevcuttur. 1967-1976 dönemini ele alan ve Asher tarafından yapılan çalışma sonucunda gelir ve gider bütçesinin her ikisinde de düşük tahminden kaynaklanan bir hata yapıldığı ve bu hatanın gider bütçesinde daha fazla olduğu görülmüştür (Asher, 1978, s. 431). Bhattacharya ve Kumari tarafından 1961-1986 dönemini kapsayan ve Theil'in eşitsizlik katsayısının yanı sıra rasyonel beklentilerin de test edildiği çalışma sonucunda gider tahminlerinde, gelire kıyasla daha fazla hata yapıldığı tespit edilmiştir. Gider tahminlerinde de; başlangıç ödenekleri tahminlerinin düşük, yılsonu ödeneği tahminlerinin ise yüksek yapıldığ 1 ve ne gelir ne de gider bütçesinin rasyonel beklentilere uygun olduğu görülmüştür (Bhattacharya ve Kumari, 1988, s. 1327). Chakraborty ve Sinha tarafından, 
1990-2004 dönemi için yapılan çalışmada ise gelir tahminlerinde gidere kıyasla daha fazla hata yapıldığı ve yapılan tahminlerin rasyonel beklentilere uygun olmadığı görülmüştür (Chakraborty ve Sinha, 2008, s. 15).

Theil'in eşitsizlik katsayılarının kullanıldığı ve Amerika Birleşik Devletleri için 19501983 dönemi için Morrison (1986) tarafından yapılan çalışma sonucunda, gider tahmininin gelire kıyasla daha başarılı olduğu tespit edilmiştir (Morrison, 1986, s. 330).

Zakaria ve Ali (2010) tarafından Pakistan'da 1987-2008 döneminde yapılan tahminler; tahmin ve gerçekleşme arasındaki fark Theil'in eşitsizlik katsayıları ve rasyonel beklentiler testi ile incelenmiştir. Sonuç olarak yılsonu ödeneklerinin başlangıç ödeneklerinden daha doğru olduğu ve 2000'li yıllarda 1990'lı yıllara kıyasla daha fazla hata yapıldığg tespit edilmiştir (Zakaria ve Ali, 2010, s. 122).

Ülkemiz açısından bu konu Günlük Şenesen (2000) tarafından, 1983-1998 dönemi için konsolide bütçe tahmin ve harcamaları kullanılarak incelenmiştir. Çalışmada, gerçekleşen harcamaların tahminin üstünde olduğu görülmüştür (Günlük Şenesen, 2000, s. 362-363). Bağdigen (2002) tarafından, 1981-2000 dönemi vergi gelirlerinin incelendiği çalışmada vergi gelirinin düşük tahmin edildiği (Bağdigen, 2002, s. 36);kamu gelir ve gider tahminleri incelendiği 2005 yılındaki yazara ait diğer çalışmada ise, gelirin yüksek harcamaların ise düşük tahmin edildiği görülmüştür (Bağdigen, 2005, s. 200).Yılmaz (2003) tarafından, hata terimleri ve Theil'in eşitsizlik katsayısının kullanıldığı ve 1980-2000 dönemini kapsayan çalışmada ise konsolide bütçe gelir ve gider tahminleri incelenmiş, her iki tahminin de düşük yapıldığ görülmüştür. Bununla birlikte yılsonu ödeneklerinin tahmininde zamanla bir iyileşme olduğu tespit edilmiştir (Y1lmaz, 2003, s. 9).

Belirtilen bu çalışmalarda kullanılan yöntemler değişiklik arz etmekle birlikte, değerlendirmelerde genel olarak tahmin hatasının ve eşitsizlik katsayısının kullanıldı̆̆ı ve yapılan tahminlerin rasyonel beklentilere uygunluğunun test edildiği görülmektedir. $\mathrm{Bu}$ noktadan hareketle çalışmada, yukarıda özetlenen değerlendirme yöntemlerinin tümü kullanılmaktadır. Çalışmanın bir sonraki bölümünde değerlendirmede kullanılan yöntemler anlatılmış üçüncü bölümde ise elde edilen sonuçlar sunulmuştur.

\section{Yöntem}

Çalışmada literatürde yer alan tahmin hatası, eşitsizlik katsayısı ve rasyonel beklentiler hipotezine yer verilecektir. Kullanılan yöntemler takip eden alt başlıklarda açıklanmıştır.

\subsection{Tahmin Hatası}


$\mathrm{Bu}$ çalışmada tahminlerin ne kadar doğru olduğunun incelenmesinde kullanılan yöntemlerden ilki tahmin hatasıdır. Tahminlerin sapma oranları olarak da ifade edilebilen tahmin hatasının hesaplanmasında gerçekleşmeden ve tahminden sapma olmak üzere iki farklı yöntem bulunmaktadır. Zakaria ve Ali (2010, s. 116) tarafindan tahmin hatas1, tahminden gerçekleşmelerin çıkarılması ile elde edilen farkın gerçekleşmelere oranlanması ile hesaplanırken; Günlük Şenesen (2000, s. 347) tarafindan bu değer gerçekleşmeden tahminlerin çıkarılması ile elde edilen farkın tahmin edilen değerlere bölünmesi suretiyle hesaplanmıştır.

Bu çalışmada tahmin hatasının hesaplanmasında Rodgers ve Joyce (1996) ve Bağdigen (2002; 2005) tarafından da kullanılan, gerçekleşmeden sapmayı gösteren tahmin hataları kullanılmıştır. Hesaplamada aşağıda yer alan formül kullanılmıştır.

$$
\text { Tahmin hatası }=\frac{\text { Gerçekleşme-Tahmin }}{\text { Gerçekleşme }} \times 100
$$

$\mathrm{Bu}$ formülden elde edilen sonuç bizlere gerçekleşen bütçe rakamlarına kıyasla tahminlerden ne kadar uzaklaşıldığını göstermektedir. Hesaplanan tahmin hatasının negatif ya da pozitif olması, bütçe tahminlerinin düşük ya da yüksek yapıldığı hakkında bilgi vermektedir. Buna göre, hesaplanan hata değerinin pozitif olması durumunda düşük tahmin yapıldığ1 söylenebilecekken, negatif olması durumunda yüksek tahmin yapıldığı söylenebilir. Hata değerinin negatif ya da pozitif olmasının yanı sıra değeri de tahmin başarısını göstermektedir. 0 değeri, tahmin edilen değerin gerçekleşmeye eş olduğu anlamına geldiğinden mükemmel tahmini ifade ederken, bu değerden ne kadar uzaklaşıldığı tahminlerde ne kadar hata yapıldığını göstermektedir.

\subsection{Eşitsizlik Katsayısı}

Tahminlerin değerlendirilmesinde kullanılan bir diğer yöntem ise Theil'in eşitsizlik katsayılarıdır. Theil (1965, s. 32) tarafından kullanılan ilk eşitsizlik katsayısı hesaplama formülü $U_{1}$ ile gösterilmiştir.

$$
U 1=\frac{\sqrt{\frac{1}{\mathrm{n}} \Sigma(\mathrm{Pt}-\mathrm{At})^{2}}}{\sqrt{\frac{1}{\mathrm{n}} \Sigma \mathrm{Pt}^{2}}+\sqrt{\frac{1}{\mathrm{n}} \Sigma \mathrm{At}^{2}}}
$$

Formülde yer alan $\mathrm{P}_{\mathrm{t}}$ tahminlerdeki değişimleri, $\mathrm{A}_{\mathrm{t}}$ gerçekleşmelerdeki değişimleri ve $\mathrm{n}$ ise gözlem sayısını ifade etmektedir. 
$\mathrm{Bu}$ formülden elde edilecek olan eşitsizlik katsayısı değeri, 0 ile 1 arasında yer almaktadır. Katsayının 0 değerini alması için bütün yıllarda tahminlerin gerçekleşmeler ile aynı olması $\left(\mathrm{P}_{\mathrm{t}}=\mathrm{A}_{\mathrm{t}}\right)$ gerektiğinden böyle bir sonucun elde edilmesi durumunda mükemmel bir tahmin yapıldığı söylenebilir. Tahmin ve gerçekleşme arasında ters orantılılı̆̆ın olması yani gerçekleşmeler negatif iken tahminin pozitif olması ya da gerçekleşmeler pozitif iken tahminin negatif olması durumunda ve değişkenlerden birinin 0 değerine sahip olması durumunda ise en üst değer olan 1 elde edilecektir (Theil, 1965, s. 33-34).

Theil (1971, s. 28) tarafından kullanılan bir diğer katsayı hesaplama formülü ise $U_{2}$ ile gösterilmiştir.

$$
U 2=\frac{\sqrt{\Sigma(\mathrm{Pt}-\mathrm{At})^{2}}}{\sqrt{\Sigma \mathrm{At}^{2}}}
$$

$\mathrm{Bu}$ formülde de $\mathrm{P}_{t}$ ve $\mathrm{A}_{t}$ değerleri tahmin ve gerçekleşmelerdeki değişimleri göstermektedir. İlk formülden farklı olarak bu formülde elde edilebilecek olan değerlerin bir üst sınırı bulunmamaktadır. Başka bir ifadeyle ilk formül ile yapılan hesaplamalarda tahmindeki değikliğin 0 olması durumunda 1 sonucu elde edilebilecekken, ikinci hesaplama formülüne göre bu değerin üstünde bir değer elde edilebilir. İki formül arasındaki bu farklılığın nedeni olarak ikinci formülün payda kısmında tahminlerdeki değişikliklere yer verilmemesi gösterilmiştir. Bunların yanı sıra birinci ve ikinci formül ile elde edilen katsayı değerinin işaretinin herhangi bir önemi bulunmamaktadır. Yani c ya da $-\mathrm{c}$ arasında bir fark bulunmamakta sadece c değeri üzerinde durulmaktadır (Theil, 1971, s. 28).

Tahminlerin başarısı değerlendirilirken kullanılan bir diğer formül ise gerçekleşme farkının ve tahminle gerçekleşme arasındaki farkın kullanıldığı ve $U_{3}$ olarak gösterilen formüldür. Bu formül Bhattacharya ve Kumari (1988, s. 1323-1324) Zakaria ve Ali (2010, s. 117) ile Chakraborty ve Sinha (2008, s. 6) tarafından yapılan değerlendirmelerde kullanılmıştır.

$$
U 3=\frac{\sqrt{\frac{1}{\mathrm{n}} \Sigma(\mathrm{P}(\mathrm{t})-\mathrm{a}(\mathrm{t}))^{2}}}{\sqrt{\frac{1}{\mathrm{n}} \Sigma \mathrm{P}(\mathrm{t})^{2}}+\sqrt{\frac{1}{\mathrm{n}} \Sigma \mathrm{a}(\mathrm{t})^{2}}}
$$

$\mathrm{Bu}$ formülde diğerlerinden farklı olarak; $\mathrm{P}_{(\mathrm{t})}=\mathrm{P}_{(\mathrm{t})}-\mathrm{A}_{(\mathrm{t}-1)}$ olarak, $\mathrm{a}_{(\mathrm{t})}=\mathrm{A}_{(\mathrm{t})}-\mathrm{A}_{(\mathrm{t}-1)}$ olarak hesaplanmıştır. $\mathrm{Bu}$ farkların haricinde diğer iki formülde olduğu gibi 0 sonucu mükemmel tahmini ifade etmektedir.

Theil (1971, s. 29) tarafından hesaplanan hata katsayıları, aşağıdaki formül ile hataya neden olan unsurlar göz önünde bulundurularak ayrıştırılmaktadır. 


$$
\frac{1}{\mathrm{n}} \Sigma(\mathrm{Pt}-\mathrm{At})^{2}=(\overline{\mathrm{Pt}}-\overline{\mathrm{At}})^{2}+(\mathrm{Sp}-\mathrm{Sa})^{2}+2(1-\mathrm{r}) \mathrm{SpSa}
$$

$\mathrm{Bu}$ formüle göre eşitliğin sol tarafında gösterilen tahmin hatalarının karelerinin ortalaması; tahmin ile gerçekleşmelerdeki farkın karesine, bu değişkenlere ait standart sapmalarının farkının karesine ve $\mathrm{r}$ ile gösterilen tahmin ile gerçekleşme arasındaki korelasyonun da yer aldığı üçüncü bir değişkene bağlıdır.

Eşitliğin sağ tarafindaki değerlerin üçü de eşitliğin toplamına bölündüğünde toplamları 1 eden $U_{m}, U_{s}$ ve $U_{c}$ ile gösterilen aşağıdaki formüller elde edilir.

$$
\begin{gathered}
\mathrm{U}_{\mathrm{m}}=\frac{\left(\overline{\left.\mathrm{P}_{\mathrm{t}}-\overline{\mathrm{A}}_{\mathrm{t}}\right)^{2}}\right.}{\frac{1}{\mathrm{n}} \Sigma\left(\mathrm{P}_{\mathrm{t}}-\mathrm{A}_{\mathrm{t}}\right)^{2}} \\
\mathrm{U}_{\mathrm{s}}=\frac{\left(\mathrm{S}_{\mathrm{p}}-\mathrm{S}_{\mathrm{a}}\right)^{2}}{\frac{1}{\mathrm{n}} \Sigma\left(\mathrm{P}_{\mathrm{t}}-\mathrm{A}_{\mathrm{t}}\right)^{2}} \\
\mathrm{U}_{\mathrm{c}}=\frac{2(1-\mathrm{r}) \mathrm{S}_{\mathrm{p}} \mathrm{S}_{\mathrm{a}}}{\frac{1}{\mathrm{n}} \Sigma\left(\mathrm{P}_{\mathrm{t}}-\mathrm{A}_{\mathrm{t}}\right)^{2}}
\end{gathered}
$$

$\mathrm{U}_{\mathrm{m}}$ ile gösterilen hata oranı tahmin edilen değiş̧ikliklerin ortalaması ile gerçekleşen değişikliklerin ortalamasının birbirinden farklı olduğunu gösterir ve bu hata oranı zaman içerisinde azaltılabilir. $U_{s}$ hata oranı ise, değerlendirmeye bazı değişkenlerin katılmaması nedeniyle artar. $U_{c}$ değeri ise, sistematik olmayan hata denilir ve tahmini yapanın iradesinin dışındadır (Theil, 1971, s. 32). İyi bir tahmin için toplamları en fazla 1 eden bu hata oranlarından $\mathrm{U}_{\mathrm{m}}$ ve $\mathrm{U}_{\mathrm{s}}$ 'nin 0 olmas1, bununla birlikte Uc'nin ise 1 olmas1 beklenmektedir (Theil, 1965, s. $37)$.

\subsection{Rasyonel Beklentiler Hipotezi}

Çalışmada kullanılan bir diğer yöntem olan rasyonel beklentiler hipotezine göre ise; tahminler, tahmin edilen değişkenle ilgili ulaş1labilir bütün geçerli bilgiler dikkate alınarak şekillendirilmelidir. Hipoteze göre, bireylerin bilgileri akıllıca kullandıkları varsayılır (Froyen, 2008, s. 229). Bilginin kısıtlı olması nedeniyle ekonomik sistemin bunu boşa harcamayacağı savunulmakla birlikte, yapılan tahminlerin sistemin genel yapısına bağlı olduğu ileri sürülür. Bilgi miktarındaki ya da sistemin yapısındaki değişikliklere bağlı olarak yapılan tahminlerin de değişmesi, duyarlı bir tahmin yapılması açısından gereklidir (Muth, 1961, s. 315).

Rasyonel beklentilerin test edilmesinde temel olarak aşağıdaki modelden yararlanılır. 


$$
A=\alpha_{0}+\alpha_{1} \mathrm{P}+\varepsilon
$$

$\mathrm{Bu}$ denklemde A gerçekleşmeleri $\mathrm{P}$ ise tahminleri göstermektedir. Formülde aranılan katsayı değerleri ise $\alpha_{0}=0 ; \alpha_{1}=1$ ve $\mathrm{E}(\varepsilon)=0$ şeklindedir. Fakat bir önceki yıl gerçekleşmesinin sonraki yılı etkilememesi de beklendiğinden yukarıdaki denklemin sağ tarafına tahmin edilen değişkenin bir önceki dönemdeki gerçekleşmesi ilave edilir ve bu değişkenin katsayı değerinin de 0 olması beklenir (Lovell, 1986, s. 113).

Bunlara ilave olarak gerçekleşme ile tahmin arasındaki fark olarak ifade edilen tahmin hatası ile tahmin arasında da bir ilişkinin olmaması da beklenmektedir (Bhattacharya ve Kumari, 1988, s. 1324). Sonuç itibariyle rasyonel beklentilerin test edilmesinde kullanılacak formül aşağıdaki gibidir.

$$
A_{t}=\alpha_{0}+\alpha_{1} \mathrm{P}_{\mathrm{t}}+\alpha_{2} \mathrm{~A}_{\mathrm{t}-1}
$$

Rasyonel beklentilere uygun olarak ödenek talep edildiğinin söylenebilmesi için karşılanması gereken kriterler şöyle ifade edilebilir. Modelde gerçekleşmeleri tahminlerden bağımsız olarak etkileyecek bir nedenin olmaması $\left(\alpha_{0}=0\right)$, bütçe gerçekleşmeleri ile tahmin arasında doğrudan bir ilişki olması $\left(\alpha_{1}=1\right)$, t zamandaki harcamaların t-1 zamandaki harcamadan etkilenmemesi $\left(\alpha_{2}=0\right)$, gerekmektedir. Son olarak tahmin ile tahmin hatas arasında herhangi bir ilişki olmaması beklenmektedir. Bu durum da tahmin ile gerçekleşme arasındaki fark olarak hesaplanan tahmin hatası ile tahmin arasındaki korelasyonun 0 olması ile sağlanacaktır $(\sigma \mathrm{E}(\mathrm{t}) \mathrm{P}(\mathrm{t})=0)($ Lovell, 1986, s. 113).

Açıklanan yöntemler özetlenecek olursa; tahmin hatası ile gerçekleşmelere ne kadar yakın tahmin yapıldığı, bir hatanın olması durumunda hatanın nedeninin düşük ya da yüksek tahmin olup olmadığı, eşitsizlik katsayılarının hesaplanması ve ayrıştırılması ile de tahminin zaman içerisinde azaltılabilecek bir nedenden mi yoksa tahmin sırasında öngörülmeyen nedenlerden mi kaynaklandığı sorularına cevap bulunabilecektir. Buna ilave olarak rasyonel beklentiler hipotezinin test edilmesi ile de aslında eşitsizlik katsayılarından elde edilen sonuçlar teyit edilebilecektir.

Yukarıda açıklanan yöntemlerden tahmin hatası ve eşitsizlik katsayısı, farklı bütçeleme sistemleri göz önünde bulundurularak ayrı olarak hesaplanmıştır. Gelir, başlangıç ve yılsonu ödenek tahminlerinin rasyonel beklentilere uygunluğunun sınanmasında, zaman serilerinde veri uzunluğunun önemli olması sebebiyle böyle bir ayrım yapılmamış, dönemin tamamı ele alınmıştır.

\section{Elde Edilen Sonuçlar}


Ülkemizde 1924 yılından itibaren klasik (geleneksel) bütçe sistemi uygulanmışken, 1973 y1lı itibariyle program bütçe sistemine geçilmiştir. Program bütçe sisteminin uygulanmasından ise 2006 yılı itibariyle, 5018 sayılı Kamu Mali Yönetimi ve Kontrol Kanunu'nun yürürlüğe girmesi ile vazgeçilmiş ve stratejik plâna dayalı performans esaslı bütçeleme sistemine geçilmiştir. Bu nedenle çalışmada daha önce de belirtildiği gibi bütçeleme sistemlerindeki değişiklikler göz önünde bulundurularak üç dönem ayrı olarak incelenmiştir.

Bütçelemede uygulanan ilk sistem olan klasik (geleneksel) bütçe sisteminde kamu hizmetlerinin yerine getirilmesi için ihtiyaç duyulan kaynakların temin edilmesine önem verilmiştir. Bu nedenle ödenek dağıtılırken öncelikle kurumların talepleri dikkate alınmaktadır. Harcamalar ile ne tür bir fayda sağlanacağının belirtilmemesi, aynı amaca yönelen harcamalar yapılabilmesine neden olmuş ve yine aynı neden uzun süreli plânlama yapılmasını engellemiştir.

Dönem için hesaplanan tahmin hataları Ek 1'de yer almaktadır. Hesaplanan bu tahmin hatalarına bakıldığında geleneksel bütçe sisteminin uygulandığı 1924-1972 döneminde gider açısından başlangıç ödeneklerinde yapılan hata oranı \% 14,58 iken yılsonu ödenek tahmini için hesaplanan oran \% 11,22'dir. Bu dönemde gelir tahminleri için hesaplanan hata oranı ise $\% 16,27$ 'dir.

1924-1972 yılları arası genel bütçe gelir ve giderlerinde yapılan tahmin hataları dikkate alınarak çizilen grafiğe Grafik 1'de yer verilmiştir.

Hata oranlarına bakıldığında en fazla tahmin hatasının gelir tahminlerinde yapıldığı gider açısından ise beklenildiği gibi yılsonu ödenek tahminlerinin başlangıç ödeneklerine kıyasla daha başarılı olduğu görülmektedir. İlave olarak dönemin genelinde gelir ve başlangıç ödenekleri tahmininin düşük, yılsonu ödeneklerinin tahmininin ise yüksek yapıldığı tespit edilmiştir. 


\section{Grafik 1: 1924-1972 Yılları Arasındaki Tahmin Hataları}

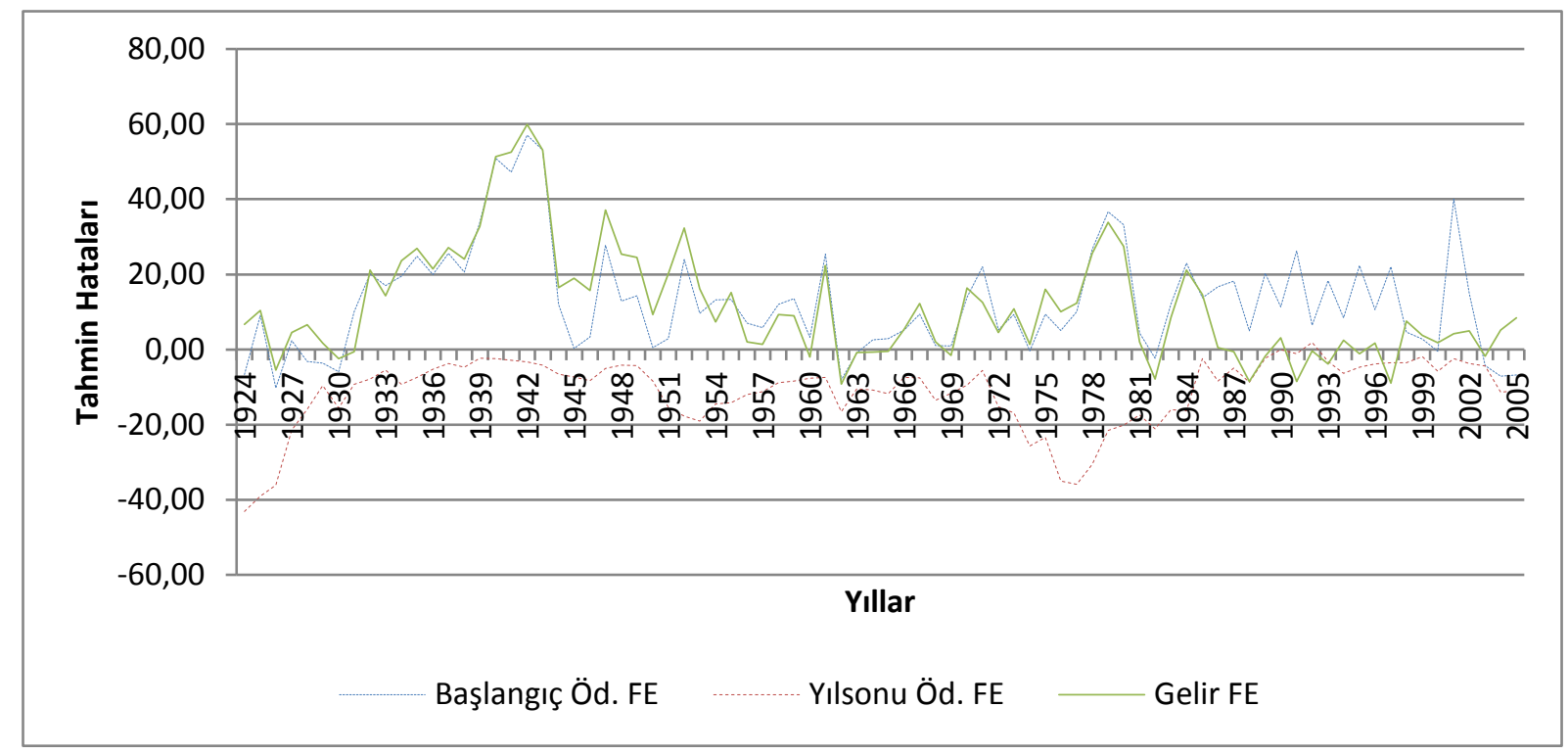

Bir sonraki dönem olan 1973-2005 yılları arasında ise bütçeleme sürecine uzun vadeli plânlamanın dâhil edildiği program bütçe sistemi uygulanmıştır. Sistem uygulanmaya başlandığında asıl hedef yapılacak olan harcamalara karar verilirken fayda maliyet analizlerinin dikkate alınması iken uygulamada bu sonuç elde edilememiştir. Geçmiş yıl taleplerinin belirli bir oranda artırılması ile cari yılda ödenek talep edilmesi nedeniyle program bütçeden tam olarak beklenilen sonuçlar elde edilememiştir.

Ek 2'de yer alan tahmin hatalarına bakılacak olursa, söz konusu dönem için ortalama olarak gelir tahminleri için \%8.20, başlangıç ödenekleri tahminlerinde \% 13.74 ve yılsonu ödenek tahminlerinde ise \% 11.38 oranında hata yapıldığı görülmektedir. $\mathrm{Bu}$ değerlere bakılacak olursa en az hatanın gelir tahminlerinde yapıldığı görülmektedir. Gider açısından ise yine beklenildiği gibi yılsonu ödenek tahmininin başlangıç ödeneklerinden daha başarılı olduğu görülmektedir. Buna ilave olarak yapılan tahminlerin gelir ve başlangıç ödenekleri tahmininin düşük, yılsonu ödenek tahminlerinin ise yüksek yapıldığı tespit edilmiştir. Dönem için hesaplanan tahmin hataları Grafik 2'de gösterilmiştir. Grafik üzerinde tahmin hatalarının yüksek ya da düşük tahminden kaynaklandığı net bir şekilde görülmektedir. 


\section{Grafik 2 1973-2005 Yılları Arasındaki Tahmin Hataları}

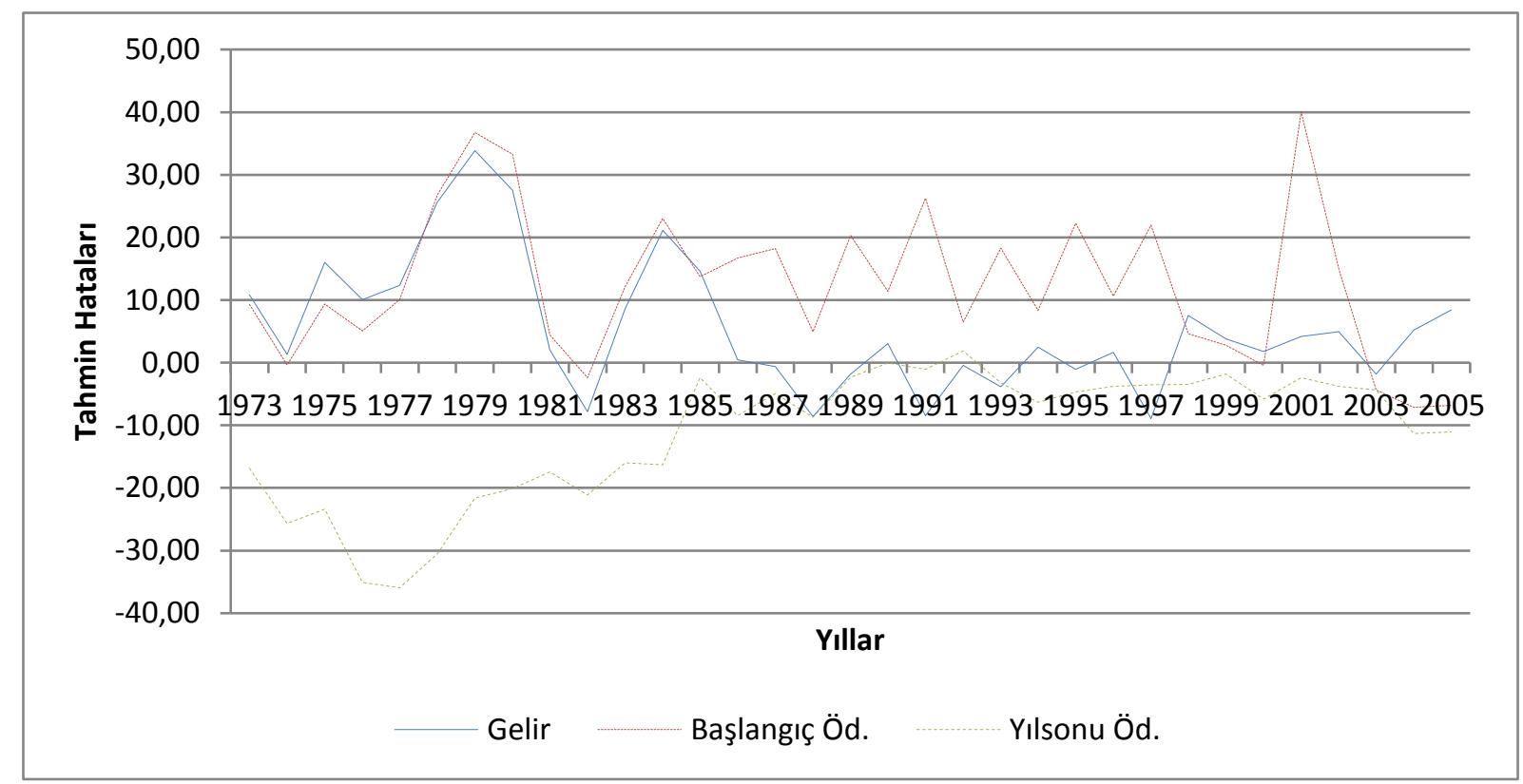

Çalışmada ele alınan son dönemde, 5018 sayılı Kamu Mali Yönetimi ve Kontrol Kanunu'nun uygulanmaya başlaması ile Stratejik Plâna Dayalı Performans Esaslı Bütçeleme Sistemi uygulanmaya başlanmıştır. Kanun ile bütçeleme sistemi stratejik plânlara dayandırılmakta ve kurumların performansları ön plâna çıkarılmaktadır. Diğer dönemlere kıyasla daha kısa olmakla birlikte bu dönemde yapılan tahminlerde bir iyileşme olduğu söylenebilmektedir. Dönem için hesaplanan tahmin hataları Ek 3'de yer almaktadır.

Performans esaslı bütçeleme sisteminin uygulandığı 2006-2015 döneminde gelir tahminlerinde \%6,6 oranında bir hata yapılmışken gider tahminleri gelir tahminlerine kıyasla daha başarılı bir tablo çizmiştir. Başlangıç ödenekleri tahmini için hesaplanan hata oranı \%2,1 iken yılsonu ödenekleri için bu oran \%3.1'dir. Önceki dönemlerde de olduğu gibi gelir tahminleri ve başlangıç ödenekleri tahminleri düşük yapılmışken, yılsonu ödenek tahminleri yüksek olarak yapılmıştır. Elde edilen tahmin hataları Grafik 3'de gösterilmiştir. 


\section{Grafik 3 2006-2015 Yılları Arasındaki Tahmin Hataları}

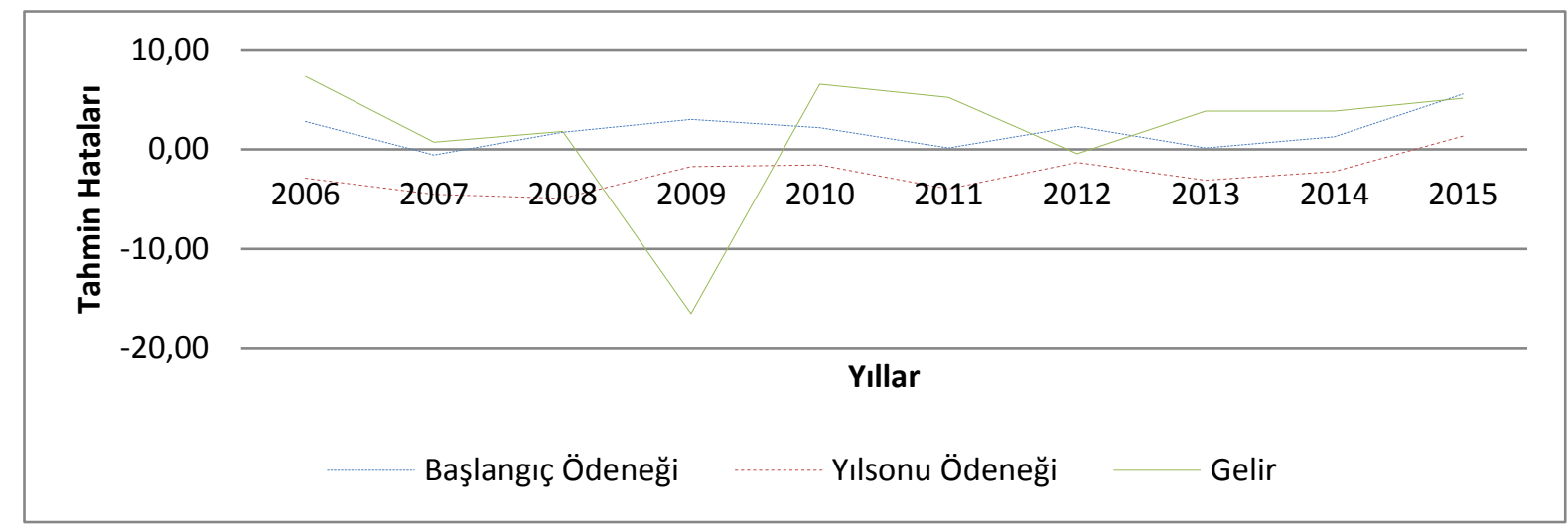

Tahminlerin gerçekleşmelere ne derece yakın olduğunu değerlendirmeye yönelik çalışmada kullanılan bir başka yöntem ise eşitsizlik katsayılarıdır. İkinci bölümde anlatıldığı gibi üç farklı eşitsizlik katsayısı hesaplama yöntemi vardır.

Öncelikle 1924-1973 dönemi için eşitsizlik katsayıları hesaplanmış ve Tablo 1'deki sonuçlar elde edilmiştir.

Tablo 1: 1924-1972 Yılları Arası Genel Bütçe Eşitsizlik Katsayıları

\begin{tabular}{|l|c|c|c|}
\hline & $\mathbf{U}_{1}$ & $\mathbf{U}_{\mathbf{2}}$ & $\mathbf{U}_{\mathbf{3}}$ \\
\hline Gelir & 0,413 & 0,805 & 0,502 \\
\hline Başlangıç Ödenekleri & 0,415 & 0,790 & 0,477 \\
\hline Yılsonu Ödenekleri & 0,077 & 0,152 & 0,087 \\
\hline
\end{tabular}

Tablodaki her üç eşitsizlik katsayısı değerlerine bakıldığında gelir ve başlangıç ödenekleri tahminlerinin başarılı olmadığını, bununla birlikte yılsonu ödenek tahminleri için hesaplanan değerin 0'a yakın olması nedeniyle daha başarılı sayılabileceğini söylenebilmektedir.

Elde edilen eşitsizlik katsayılarının hataya neden olan etmenlere ayrıştırılması ile elde edilen sonuçlar Tablo 2'de gösterilmiştir. İkinci bölümde ifade edildiği gibi toplamları 1 olan ve sapma, değişim, rassal olarak adlandırılan bu üç hata nedeninden sapma ve değişimin 0 olması beklenirken, rassal nedenlerden kaynaklanan hata değerinin 1 olması beklenmektedir. 
Tablo 2: 1924-1972 Döneminde Tahminde Tespit Edilen Hatanın Kaynakları

\begin{tabular}{|l|c|c|c|}
\hline & Sapma & Değişim & Rassal \\
\hline Gelir & 0,002 & 0,005 & 1,011 \\
\hline Başlangıç Ödeneği & 0,007 & 0,017 & 0,994 \\
\hline Yılsonu Ödeneği & 0,010 & 0,017 & 0,993 \\
\hline
\end{tabular}

Tablo-2'deki sonuçlara bakılacak olursa tahminlerdeki başarısızlığın nedeninin yanlış hesaplamalardan, değerlendirmelerden kaynaklanmadığı bununla birlikte rassal olarak adlandırılan öngörme ihtimalinin olmadığı nedenlerden kaynaklandığı söylenebilir.

Bir sonraki dönem olan 1973-2005 dönemi için hesaplanan eşitsizlik katsayıları Tablo 3'de gösterilmiştir. Önceki dönemde olduğu gibi bu dönemde de y1lsonu ödenek tahminlerinin gelir tahmini ve başlangıç ödenekleri tahminine kıyasla daha başarılı olduğunu görülmektedir. Bununla birlikte $U_{1}$ ve $U_{2}$ sonuçlarına göre bir önceki döneme kıyasla daha başarılı tahminlerin yapıldığııı, başka bir ifade ile zamanla yapılan tahminlerin iyileştiğini söylenebilmektedir. $\mathrm{U}_{3}$ açısından ise başlangıç ve yılsonu ödeneklerinin tahmininde önceki döneme kıyasla başarısız olduğu görülürken gelir tahminleri açısından bir önceki döneme yakın değerler elde edilmiştir.

Tablo 3 1973-2005 Dönemi Eşitsizlik Katsayıları

\begin{tabular}{|l|c|c|c|}
\hline & $\mathbf{U}_{\mathbf{1}}$ & $\mathbf{U}_{\mathbf{2}}$ & $\mathbf{U}_{\mathbf{3}}$ \\
\hline Gelir & 0,128 & 0,259 & 0,498 \\
\hline Başlangıç Ödeneği & 0,203 & 0,423 & 0,762 \\
\hline Yılsonu Ödeneği & 0,048 & 0,096 & 0,191 \\
\hline
\end{tabular}

1973-2005 dönemi için hesaplanan tahmin hatalarının nedenlerine bakıldığında ise bir önceki dönemde olduğu gibi hataların büyük bir kısmının rassal nedenlerden kaynaklandığını görülmektedir. Hatanın ayrıştırılması sonucunda elde edilen sonuçlar Tablo 4'de sunulmuştur.

Tablo 4: 1973-2005 Döneminde Tahminde Tespit Edilen Hatanın Kaynakları

\begin{tabular}{|l|c|c|c|}
\hline & Sapma & Değişim & Rassal \\
\hline Gelir & 0,011 & 0,016 & 1,014 \\
\hline Başlangıç Ödeneği & 0,021 & 0,065 & 0,954 \\
\hline Yılsonu Ödeneği & 0,010 & 0,000 & 1,032 \\
\hline
\end{tabular}


Çalışmada ele alınan son dönem olan, performans esaslı bütçeleme sisteminin uygulandığı 2006-2015 dönemine ilişkin olarak hesaplanan eşitsizlik katsayıları ise Tablo 5'de gösterilmiştir. Katsayılara bakıldığında yapılan bütçe tahminlerinin daha doğru olduğu söylenebilir. Fakat bu noktada ele alınan dönemin diğer dönemlere kıyasla daha kısa olduğunun göz ardı edilmemesi gerekmektedir.

Tablo 5: 2006-2015 Dönemi Eşitsizlik Katsayıları

\begin{tabular}{|l|c|c|c|}
\hline & U1 & U2 & U3 \\
\hline Gelir & 0,029 & 0,056 & 0,263 \\
\hline Başlangıç Ödeneği & 0,016 & 0,031 & 0,150 \\
\hline Yılsonu Ödeneği & 0,018 & 0,037 & 0,108 \\
\hline
\end{tabular}

Bütçe tahminlerinin başarısının değerlendirilmesinde çalışma kapsamında ele alınan son yöntem ise tahminlerin rasyonel beklentilere uygunluğunun test edilmesidir. Böyle bir testin yapılması ise ikinci bölümde açıklanan ekonometrik modelin sınanması ile mümkündür.

Zaman serilerinin ekonometrik analizlerde kullanılabilmesi için öncelikle değişkenlerin durağanlıklarının sağlanması gerekmektedir. En yalın haliyle durağanlık kavramı; bir zaman serisinde, seriye ait ortalama ve varyans gibi değerlerin sürekli bir artma ya da azalma göstermemesi olarak açıklanabilir. Başka bir açıdan sonucu yorumlayacak olursak; eğer bir seri durağansa gerçekleşen tek bir veri setinden uzun zaman serisine ait ortalama ve varyansın hesaplanabilmesi mümkün olabilecektir (Enders, 2010, s. 53-54). Zaman serilerinde nominal verilerin, durağanlık koşulunu sağlamasının zor olması nedeniyle öncelikle bütün değişkenlerin logaritmaları alınmıştır. 1923-2015 dönemi için logaritmaları alınan değişkenlere ait durağanlık sınaması test sonuçları Tablo 6'da gösterilmiştir.

Tablo 6: Modeldeki Değişkenler İçin Durağanlık Sınaması

\begin{tabular}{|l|l|c|c|c|c|}
\hline \multirow{2}{*}{} & \multirow{2}{*}{} & \multicolumn{2}{|c|}{ ADF } & \multicolumn{2}{c|}{ KPSS } \\
\cline { 3 - 6 } & & trendsiz & trendli & trendsiz & trendli \\
\hline \multirow{2}{*}{$\cong$} & $\operatorname{lngt}$ & 0.9216 & 0.3284 & $1.1678^{*}$ & $0.2966^{*}$ \\
\cline { 2 - 6 } & dlngt & 0.3606 & 0.6965 & $0.5948^{* *}$ & $0.1395^{* * *}$ \\
\cline { 2 - 6 } & $\operatorname{lngg}$ & 0.9901 & 0.6272 & $1.1666^{*}$ & $0.2985^{*}$ \\
\hline
\end{tabular}




\begin{tabular}{|c|c|c|c|c|c|}
\hline & dlngg & $0.0478^{* *}$ & $0.0920 * * *$ & $0.5864 * *$ & $0.1350 * * *$ \\
\hline \multirow{6}{*}{$\begin{array}{l}\stackrel{1}{T} \\
\text { 궁 }\end{array}$} & lnbasl & 0.8088 & 0.2572 & $1.1658 *$ & $0.2947 *$ \\
\hline & dlnbasl & $0.0933 * * *$ & 0.1985 & $0.5615 * *$ & $0.1369 * * *$ \\
\hline & lny1ls & 0.9340 & 0.5039 & $1.1670 *$ & $0.2958 *$ \\
\hline & dlny1ls & 0.2234 & 0.5527 & $0.5526 * *$ & $0.1375 * * *$ \\
\hline & lngerc & 0.9877 & 0.5278 & $1.1666^{*}$ & $0.2955^{*}$ \\
\hline & dlngerc & $0.0343 * *$ & $0.0810 * * *$ & $0.5412 * *$ & $0.1367 * * *$ \\
\hline
\end{tabular}

Not: Tabloda yer alan *, ** ve *** sirasıyla $\% 1, \% 5$ ve $\% 10$ anlamllık derecesini göstermektedir.

Tablo 6' da gösterilen "gg" ve "gt"; tahsil edilen geliri ve tahmin edilen gelir tahsilâtını göstermektedir. Gider açısından ise "basl” başlangıç ödeneğini, "yıls" yılsonu ödeneğini ve "gerc" de gerçekleşen harcamayı göstermektedir. Logaritmaları alınan seriler "In" ile fark alınan değişkenler ise "dln" ile gösterilmiştir.

Zaman serisi değişkenlerinde deterministik trend olma ihtimali göz önünde bulundurularak, yapılan geleneksel Artırılmış Dickey-Fuller (ADF) ve KPSS (KwiathowskiPhillips-Schmidt-Shin)durağanlık sınamalarında elde edilen sonuçlar trendin olduğu ve olmadığı iki durum için ayrı ayrı gösterilmiştir. Zira KPSS birim kök testinde amaç Sevüktekin ve Çınar'a göre gözlenen serideki deterministik trendin arındırılarak serinin durağanlaştırılmasıdır ve bu testteki durağanlık trend durağanlığı ifade etmektedir(Sevüktekin ve Çınar, 2014, s. 376). Trend durağanlık ise gerçekte durağan olan bir zaman serisinin, serinin deterministik trende sahip olması durumunda durağan dışı bir yapı sergilemesidir. Durağan dışı zaman serisini durağan hale dönüştürmek için, kullanılacak olan modele trendin bir değişken olarak eklenmesi ile gerekli analizlerin yapılması tercih edilebilir (Sevüktekin ve Çınar, 2014, s. 244).

Yukarıdaki tabloda da görüleceği gibi logaritması alınan değişkenlerin tamamı KPSS test sonuçlarına göre durağandır. Fakat değişkenlerin, trend durağan olması nedeniyle kullanılacak olan modele trend eklenmesi gerekmektedir. 8 numaralı formüle trendin eklenmesi ile çalışmada kullanılan model elde edilmiştir. Elde edilen test sonuçları Tablo 7'de gösterilmiştir.

$$
A_{t}=\alpha_{0}+t+\alpha_{1} P_{t}+\alpha_{2} A_{t-1}
$$


Tablo 7: Genel Bütçe Gelir ve Giderleri Rasyonel Beklentiler Hipotezi Test Sonuçları

\begin{tabular}{|c|c|c|c|c|c|c|c|c|}
\hline & & & $\alpha_{0}$ & $\mathrm{t}$ & $\alpha_{1}$ & $\alpha_{2}$ & $\mathrm{R}^{2}$ & $\sigma$ \\
\hline & : & 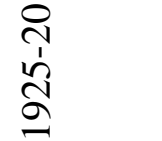 & $\begin{array}{l}0.2002 \\
* * *\end{array}$ & $\begin{array}{l}0.0017 \\
* * *\end{array}$ & $\begin{array}{l}0.6147 \\
* * *\end{array}$ & $\begin{array}{l}0.3768 \\
* * *\end{array}$ & 0.9996 & -0.4700 \\
\hline & & & $\alpha_{0}$ & $\mathrm{t}$ & $\alpha_{1}$ & $\alpha_{2}$ & $\mathrm{R}^{2}$ & $\Sigma$ \\
\hline$\overline{\bar{\theta}}$ & 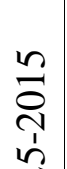 & 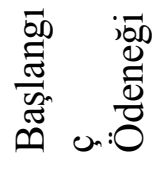 & $\begin{array}{l}0.1816 \\
* * *\end{array}$ & 0.0027 & $\begin{array}{l}0.7044 \\
* * *\end{array}$ & $\begin{array}{l}0.2850 \\
* * *\end{array}$ & 0.9995 & -0.3928 \\
\hline & 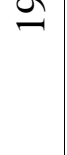 & 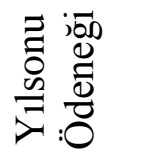 & $\begin{array}{l}-0.1243 \\
* * *\end{array}$ & -0.0011 & $\begin{array}{l}0.9280 \\
* * *\end{array}$ & $\begin{array}{l}0.0802 \\
* * *\end{array}$ & 0.9999 & -0.4200 \\
\hline
\end{tabular}

Not: Tabloda yer alan $* * *, * *$ ve $*$ sirasıyla $\% 1, \% 5$ ve $\% 10$ anlamlılık düzeylerini ifade etmektedir.

Gelir tahminlerinin rasyonelliği için kurulan modelde bütün değişkenler istatistikî olarak anlamlıdır. Değişkenler için yapılan kısıt testi sonucunda sabit terimin 0'dan; tahmine ait katsayısının 1'den ve gerçekleşmenin gecikmelisine ait katsayının ise 0'dan farklı olduğu tespit edilmiştir. Hesaplanan hata terimi ile tahmin arasındaki ilişkiyi gösteren ve $\sigma$ ile ifade edilen korelasyon katsayısı ise 0 değildir. Bu hata terimlerinin yapılan tahminlerden bağımsız olma koşulunun sağlanmadığını göstermektedir. Sonuç olarak gelir tahminlerinin rasyonel beklentileri karşılamadı̆̆ tespit edilmiştir.

Gider tahminleri açısından ise başlangıç ödeneği tahminlerinde, sabit terime, tahmine ve bir önceki yıla ait gerçekleşmeye ait katsayılar anlamlı iken anlamlı olan bu katsayılar aranılan değerlerden farklılık göstermektedir. Yılsonu ödenek tahminleri için de yine bütün değişkenler anlamlı olmakla birlikte aranılan değerleri karşılamamaktadır.

Sonuç olarak gelir ve gider tahminlerine ilişkin olarak yapılan rasyonel beklentiler sınamasında, yapılan ödenek taleplerinin ve gelir tahminlerinin rasyonel beklentilere uygun olarak yapılmadığı tespit edilmiştir.

\section{Sonuç}

Çalışmada bütçenin bir tahmin belgesi olmasından hareketle, yapılan tahminlerin bütçe ilkelerinden doğruluk ve samimiyet ilkelerine ne derece uygun olduğu incelenmiştir. Zira bütçe 
tahminleri yapılırken günümüzde stratejik plânlarla daha öncesinde ise kalkınma planları ile ilişki kurulduğundan belirlenen hedeflerin elde edilmesi, büyük ölçüde bütçelerin doğru olarak hazırlanmasıyla ilişkilidir.

Gelir bütçesinde tahmin başarısının farklı bütçeleme sistemlerinden etkilenip etkilenmediğine hakkında yapılan tahmin hatalarına bakılarak bir yorum yapılabilir. Geleneksel bütçe sisteminin uygulandığı dönemde gelir tahmininde \%16,27 oranında hata yapılmışken, program bütçe sisteminin uygulandığı dönemde bu oran $\% 8,20$, performans esaslı bütçeleme sisteminin uygulandığ dönem içinse \% 5,5 olarak hesaplanmıştır. Belirtilen hataların aynı uzunlukta bir dönemi kapsamadığı bilinmekle birlikte zaman içerisinde gelir tahminlerinde bir iyileşmenin olduğu söylenebilmektedir.

Tahmin hatalarına bakıldığında geleneksel bütçe sisteminin uygulandığı 1924-1972 döneminde gider açısından başlangıç ödeneklerinde yapılan hata oranı \% 14,58 iken yılsonu ödenek tahmini için hesaplanan oran \% 11,22'dir. Bir sonraki dönem için hesaplanan tahmin hatalarına göre bütçeleme sistemindeki değişikliğin bütçe tahminlerinde bir iyileşmeye neden olmadığ 1 görülmektedir. Bu dönem için hesaplanan hata oranları ise başlangıç ödeneklerinde \% 13,74, yılsonu ödeneklerinde ise \% 11,38 olarak hesaplanmıştır. Stratejik plânlarla ilişkilendirilerek bütçe tahminin yapıldığı 2006-2015 döneminde ise gider tahminleri daha başarılı bir tablo çizmektedir. Dönem içerisinde yapılan ortalama hata değerlerine bakıldığında başlangıç ödeneklerinde \% 1,8, yılsonu ödeneklerinde ise \%3 oranında hata yapıldı̆̆ görülmektedir.

Dönemler için hesaplanan eşitsizlik katsayılarından hareketle ülkemizde bütçe gelir ve gider tahminlerinde zaman içerisinde bir iyileşmenin olduğu görülmektedir. Özellikle yılsonu ödenek tahminleri, tahmin hatası hesaplamalarında da olduğu gibi, gelir ve başlangıç ödeneği tahminine kıyasla beklenildiği gibi daha başarılıdır.

Bütçeleme aşamasında rasyonel beklentiler hipotezinin geçerliliğinin sınanması sonucunda ise elde edilen katsayıların beklenen değerlerde olmaması nedeniyle olumsuz sonuç elde edilmiştir.

Elde edilen sonuçlar 1şığında zamanla bütçe tahminlerinde iyileşme olduğu görülse de; doğruluk ve samimiyet ilkeleri ile rasyonel beklentiler hipotezine uygun bütçe gelir ve gider tahminlerine ihtiyaç olduğu görülmektedir. İlave olarak stratejik plânlara uygun harcamaların yapılması ve yapılan harcamaları denetleyen iç ve dış denetim mekanizmalarının işlerliğinin artırılmasının daha doğru tahminlerin yapılmasını sağlayacağı düşünülmektedir. 


\section{Ekler}

Ek 1: 1924-1972 Yılları Arası Genel Bütçe Gelir ve Gider Tahmin Hataları

\begin{tabular}{|c|c|c|c|c|c|c|c|c|c|c|c|c|c|}
\hline \multirow[b]{2}{*}{ Yillar } & \multicolumn{2}{|c|}{ GELİR } & \multicolumn{2}{|c|}{$\begin{array}{c}\text { GIDER } \\
\text { Başlangıç Ödenekleri }\end{array}$} & \multicolumn{2}{|c|}{$\begin{array}{c}\text { GİDER } \\
\text { Yılsonu Ödenekleri }\end{array}$} & & \multicolumn{2}{|c|}{ GELİR } & \multicolumn{2}{|c|}{$\begin{array}{c}\text { GIDER } \\
\text { Başlanglç } \\
\text { Ödenekleri }\end{array}$} & \multicolumn{2}{|c|}{$\begin{array}{c}\text { GİDER } \\
\text { Yılsonu Ödenekleri }\end{array}$} \\
\hline & $\begin{array}{c}\text { Tahmin } \\
\text { Hatası } \\
\text { (TH) }\end{array}$ & $|\mathbf{T H}|$ & $\begin{array}{c}\text { Tahmin } \\
\text { Hatası } \\
\text { (TH) }\end{array}$ & $|\mathbf{T H}|$ & $\begin{array}{c}\text { Tahmin } \\
\text { Hatası } \\
\text { (TH) }\end{array}$ & $|\mathbf{T H}|$ & Yillar & $\begin{array}{c}\text { Tahmin } \\
\text { Hatası } \\
\text { (TH) }\end{array}$ & $|\mathbf{T H}|$ & $\begin{array}{c}\text { Tahmin } \\
\text { Hatası } \\
\text { (TH) }\end{array}$ & $|\mathbf{T H}|$ & $\begin{array}{c}\text { Tahmin } \\
\text { Hatası } \\
\text { (TH) }\end{array}$ & $|\mathbf{T H}|$ \\
\hline 1924 & 6,65 & 6,65 & $-6,72$ & 6,72 & $-43,13$ & 43,13 & 1949 & 24,54 & 24,54 & 14,29 & 14,29 & $-4,29$ & 4,29 \\
\hline 1925 & 10,37 & 10,37 & 9,10 & 9,10 & $-39,06$ & 39,06 & 1950 & 9,35 & 9,35 & 0,54 & 0,54 & $-8,43$ & 8,43 \\
\hline 1926 & $-5,49$ & 5,49 & $-10,24$ & 10,24 & $-36,11$ & 36,11 & 1951 & 20,12 & 20,12 & 2,86 & 2,86 & $-15,36$ & 15,36 \\
\hline 1927 & 4,47 & 4,47 & 2,35 & 2,35 & $-21,41$ & 21,41 & 1952 & 32,36 & 32,36 & 23,97 & 23,97 & $-17,78$ & 17,78 \\
\hline 1928 & 6,54 & 6,54 & $-3,18$ & 3,18 & $-15,91$ & 15,91 & 1953 & 16,14 & 16,14 & 9,63 & 9,63 & $-19,08$ & 19,08 \\
\hline 1929 & 1,69 & 1,69 & $-3,59$ & 3,59 & $-9,64$ & 9,64 & 1954 & 7,30 & 7,30 & 13,24 & 13,24 & $-14,50$ & 14,50 \\
\hline 1930 & $-2,39$ & 2,39 & $-5,97$ & 5,97 & $-15,61$ & 15,61 & 1955 & 15,19 & 15,19 & 13,36 & 13,36 & $-14,20$ & 14,20 \\
\hline 1931 & $-0,59$ & 0,59 & 10,10 & 10,10 & $-9,28$ & 9,28 & 1956 & 2,07 & 2,07 & 7,06 & 7,06 & $-12,01$ & 12,01 \\
\hline 1932 & 21,09 & 21,09 & 20,21 & 20,21 & $-7,86$ & 7,86 & 1957 & 1,31 & 1,31 & 5,86 & 5,86 & $-11,25$ & 11,25 \\
\hline 1933 & 14,28 & 14,28 & 17,01 & 17,01 & $-5,46$ & 5,46 & 1958 & 9,26 & 9,26 & 12,02 & 12,02 & $-8,89$ & 8,89 \\
\hline 1934 & 23,67 & 23,67 & 19,55 & 19,55 & $-9,24$ & 9,24 & 1959 & 9,00 & 9,00 & 13,50 & 13,50 & $-8,41$ & 8,41 \\
\hline 1935 & 26,91 & 26,91 & 24,84 & 24,84 & $-7,49$ & 7,49 & 1960 & $-1,99$ & 1,99 & 3,25 & 3,25 & $-7,64$ & 7,64 \\
\hline 1936 & 21,42 & 21,42 & 19,96 & 19,96 & $-5,31$ & 5,31 & 1961 & 22,29 & 22,29 & 25,34 & 25,34 & $-7,41$ & 7,41 \\
\hline 1937 & 27,15 & 27,15 & 25,64 & 25,64 & $-3,76$ & 3,76 & 1962 & $-9,21$ & 9,21 & $-8,08$ & 8,08 & $-16,57$ & 16,57 \\
\hline 1938 & 24,08 & 24,08 & 20,57 & 20,57 & $-4,71$ & 4,71 & 1963 & $-0,82$ & 0,82 & $-0,87$ & 0,87 & $-10,51$ & 10,51 \\
\hline
\end{tabular}




\begin{tabular}{|c|c|c|c|c|c|c|c|c|c|c|c|c|c|}
\hline 1939 & 32,74 & 32,74 & 33,81 & 33,81 & $-2,33$ & 2,33 & 1964 & $-0,74$ & 0,74 & 2,58 & 2,58 & $-10,76$ & 10,76 \\
\hline 1940 & 51,38 & 51,38 & 50,88 & 50,88 & $-2,43$ & 2,43 & 1965 & $-0,53$ & 0,53 & 2,87 & 2,87 & $-11,75$ & 11,75 \\
\hline 1941 & 52,51 & 52,51 & 47,18 & 47,18 & $-2,90$ & 2,90 & 1966 & 5,42 & 5,42 & 5,16 & 5,16 & $-7,45$ & 7,45 \\
\hline 1942 & 59,92 & 59,92 & 57,07 & 57,07 & $-3,27$ & 3,27 & 1967 & 12,26 & 12,26 & 9,44 & 9,44 & $-7,52$ & 7,52 \\
\hline 1943 & 53,13 & 53,13 & 53,07 & 53,07 & $-4,16$ & 4,16 & 1968 & 2,02 & 2,02 & 1,01 & 1,01 & $-13,50$ & 13,50 \\
\hline 1944 & 16,47 & 16,47 & 12,05 & 12,05 & $-6,61$ & 6,61 & 1969 & $-1,62$ & 1,62 & 0,91 & 0,91 & $-11,70$ & 11,70 \\
\hline 1945 & 18,99 & 18,99 & 0,27 & 0,27 & $-7,31$ & 7,31 & 1970 & 16,33 & 16,33 & 13,91 & 13,91 & $-9,47$ & 9,47 \\
\hline 1946 & 15,67 & 15,67 & 3,29 & 3,29 & $-8,28$ & 8,28 & 1971 & 12,61 & 12,61 & 22,05 & 22,05 & $-5,62$ & 5,62 \\
\hline 1947 & 37,15 & 37,15 & 27,75 & 27,75 & $-5,03$ & 5,03 & 1972 & 4,54 & 4,54 & 5,24 & 5,24 & $-15,28$ & 15,28 \\
\hline 1948 & 25,36 & 25,36 & 12,83 & 12,83 & $-4,19$ & 4,19 & Ortalama & 15,31 & 16,27 & 13,00 & 14,58 & $-11,22$ & 11,22 \\
\hline
\end{tabular}

Kaynak: T.C. Maliye ve Gümrük Bakanlığı Bütçe ve Mali Kontrol Genel Müdürlüğü, 1992 ‘den alınan verilerden derlenmiştir. 
Ek 2: 1973-2005 Y1lları Arası Genel Bütçe Gelir ve Gider Tahmin Hataları

\begin{tabular}{|c|c|c|c|c|c|c|}
\hline \multirow[b]{2}{*}{ Yillar } & \multicolumn{2}{|l|}{ GELİR } & \multicolumn{2}{|c|}{$\begin{array}{l}\text { GIDER } \\
\text { Başlangıç Ödenekleri }\end{array}$} & \multicolumn{2}{|c|}{$\begin{array}{l}\text { GIDER } \\
\text { Yılsonu Ödenekleri }\end{array}$} \\
\hline & $\begin{array}{l}\text { Tahmin } \\
\text { Hatası (TH) }\end{array}$ & $|\mathbf{T H}|$ & $\begin{array}{l}\text { Tahmin } \\
\text { Hatası (TH) }\end{array}$ & $|\mathbf{T H}|$ & \begin{tabular}{|l} 
Tahmin \\
Hatası (TH)
\end{tabular} & $|\mathbf{T H}|$ \\
\hline 1973 & 10,80 & 10,80 & 9,33 & 9,33 & $-16,86$ & 16,86 \\
\hline 1974 & 1,32 & 1,32 & $-0,35$ & 0,35 & $-25,67$ & 25,67 \\
\hline 1975 & 15,99 & 15,99 & 9,36 & 9,36 & $-23,41$ & 23,41 \\
\hline 1976 & 10,05 & 10,05 & 5,08 & 5,08 & $-35,07$ & 35,07 \\
\hline 1977 & 12,31 & 12,31 & 10,06 & 10,06 & $-35,93$ & 35,93 \\
\hline 1978 & 25,63 & 25,63 & 26,72 & 26,72 & $-30,55$ & 30,55 \\
\hline \begin{tabular}{|l|}
1979 \\
\end{tabular} & 33,86 & 33,86 & 36,72 & 36,72 & $-21,60$ & 21,60 \\
\hline 1980 & 27,49 & 27,49 & 33,26 & 33,26 & $-20,12$ & 20,12 \\
\hline 1981 & 2,03 & 2,03 & 4,44 & 4,44 & $-17,45$ & 17,45 \\
\hline 1982 & $-7,83$ & 7,83 & $-2,37$ & 2,37 & $-21,14$ & 21,14 \\
\hline 1983 & 8,58 & 8,58 & 12,15 & 12,15 & $-16,01$ & 16,01 \\
\hline 1984 & 21,15 & 21,15 & 23,04 & 23,04 & $-16,33$ & 16,33 \\
\hline 1985 & 14,63 & 14,63 & 13,72 & 13,72 & $-2,39$ & 2,39 \\
\hline 1986 & 0,45 & 0,45 & 16,67 & 16,67 & $-8,44$ & 8,44 \\
\hline 1987 & $-0,61$ & 0,61 & 18,24 & 18,24 & $-4,94$ & 4,94 \\
\hline 1988 & $-8,57$ & 8,57 & 4,97 & 4,97 & $-8,69$ & 8,69 \\
\hline 1989 & $-1,81$ & 1,81 & 20,31 & 20,31 & $-2,34$ & 2,34 \\
\hline 1990 & 3,05 & 3,05 & 11,41 & 11,41 & $-0,08$ & 0,08 \\
\hline 1991 & $-8,49$ & 8,49 & 26,26 & 26,26 & $-1,09$ & 1,09 \\
\hline 1992 & $-0,42$ & 0,42 & 6,49 & 6,49 & 1,87 & 1,87 \\
\hline 1993 & $-3,86$ & 3,86 & 18,28 & 18,28 & $-3,19$ & 3,19 \\
\hline 1994 & 2,49 & 2,49 & 8,38 & 8,38 & $-6,32$ & 6,32 \\
\hline 1995 & $-1,10$ & 1,10 & 22,29 & 22,29 & $-4,70$ & 4,70 \\
\hline 1996 & 1,67 & 1,67 & 10,60 & 10,60 & $-3,80$ & 3,80 \\
\hline 1997 & $-8,92$ & 8,92 & 21,96 & 21,96 & $-3,51$ & 3,51 \\
\hline 1998 & 7,53 & 7,53 & 4,64 & 4,64 & $-3,50$ & 3,50 \\
\hline 1999 & 3,79 & 3,79 & 2,79 & 2,79 & $-1,86$ & 1,86 \\
\hline 2000 & 1,76 & 1,76 & $-0,44$ & 0,44 & $-5,83$ & 5,83 \\
\hline 2001 & 4,19 & 4,19 & 40,06 & 40,06 & $-2,42$ & 2,42 \\
\hline 2002 & 4,94 & 4,94 & 14,90 & 14,90 & $-3,78$ & 3,78 \\
\hline 2003 & $-1,82$ & 1,82 & $-4,33$ & 4,33 & $-4,35$ & 4,35 \\
\hline 2004 & 5,17 & 5,17 & $-7,13$ & 7,13 & $-11,31$ & 11,31 \\
\hline 2005 & 8,42 & 8,42 & $-6,81$ & 6,81 & $-11,04$ & 11,04 \\
\hline Ortalama & 5,57 & 8,20 & 12,45 & 13,74 & $-11,27$ & 11,38 \\
\hline
\end{tabular}

Kaynak: T.C. Maliye ve Gümrük Bakanlığı Bütçe ve Mali Kontrol Genel Müdürlüğü, 1992 ve Muhasebat Genel Müdürlüğü'nden alınan verilerden derlenmiştir. 
Ek 3: 2006-2015 Y1lları Arası Genel Bütçe Gelir ve Gider Tahmin Hataları

\begin{tabular}{|c|c|c|c|c|c|c|}
\hline \multirow{2}{*}{ Yıllar } & \multicolumn{2}{|c|}{ GELIR } & \multicolumn{2}{c|}{$\begin{array}{c}\text { GidEER } \\
\text { Başlangıç Ödeneği }\end{array}$} & \multicolumn{2}{c|}{$\begin{array}{c}\text { GiDER } \\
\text { Yılsonu Ödeneği }\end{array}$} \\
\cline { 2 - 7 } & $\begin{array}{c}\text { Tahmin } \\
\text { Hatası } \\
\text { (TH) }\end{array}$ & $|\mathbf{T H}|$ & $\begin{array}{c}\text { Tahmin } \\
\text { Hatası } \\
\text { (TH) }\end{array}$ & $|\mathbf{T H}|$ & $\begin{array}{c}\text { Tahmin } \\
\text { Hatası } \\
\text { (TH) }\end{array}$ & \\
\hline 2006 & 7,32 & 7,32 & 2,81 & 2,81 & $-2,90$ & 2,90 \\
\hline 2007 & 0,73 & 0,73 & $-0,57$ & 0,57 & $-4,50$ & 4,50 \\
\hline 2008 & 1,78 & 1,78 & 1,70 & 1,70 & $-4,91$ & 4,91 \\
\hline 2009 & $-16,46$ & 16,46 & 3,01 & 3,01 & $-1,71$ & 1,71 \\
\hline 2010 & 6,55 & 6,55 & 2,18 & 2,18 & $-1,57$ & 1,57 \\
\hline 2011 & 5,20 & 5,20 & 0,13 & 0,13 & $-3,97$ & 3,97 \\
\hline 2012 & $-0,45$ & 0,45 & 2,30 & 2,30 & $-1,30$ & 1,30 \\
\hline 2013 & 3,84 & 3,84 & 0,14 & 0,14 & $-3,12$ & 3,12 \\
\hline 2014 & 3,84 & 3,84 & 1,28 & 1,28 & $-2,23$ & 2,23 \\
\hline 2015 & 5,12 & 5,12 & 5,54 & 5,54 & 1,33 & 1,33 \\
\hline Ortalama & $\mathbf{1 , 7 5}$ & $\mathbf{5 , 1 3}$ & $\mathbf{1 , 8 5}$ & $\mathbf{1 , 9 7}$ & $\mathbf{- 2 , 4 9}$ & $\mathbf{2 , 7 5}$ \\
\hline
\end{tabular}

Kaynak: Muhasebat Genel Müdürlüğü, Bütçe İstatistikleri’nden alınan verilerinden derlenmiştir. 


\section{Kaynakça}

Allan, C. M. (1965). Fiscal Marksmanship, 1951-63. Oxford Economic Papers, 317-327.

Asher, M. G. (1978). Accuracy of Budgetary Forecast of Central Government, 1967-68 to1975-76. Economic and Political Weekly, 423-432.

Auld, D. A. (1970). Fiscal Marksmanship in Canada. The Canadian Journal of Economics, 507-511.

Bağdigen, M. (2002). How Accurate is Revenue Forecasting in Turkey? An Empirical Analysis. Yapı Kredi Economic Review, Vol. 13, No. 2, 29-37.

Bağdigen, M. (2005). An Empirical Analysis of Accurate Budget Forecasting in Turkey. Doğuş Üniversitesi Dergisi, 6(2), 190-201.

Bhattacharya, B. B., \& Kumari, A. (1988). Budget Forecast of Central Government Revenue and Expenditure: A Test of Rational Expectation. Economic and Political Weekly, Vol.23, No.26, 1323-1327.

Chakraborty, L. S., \& Sinha, D. (2008). Budgetary Forecasting in India: Partitioning Errors and Testing for Rational Expectations. Munich Personal RePEc Archive (MPRA) Working Paper No. 7538.

Coşkun, G. (2000). Devlet Bütçesi. Ankara: Turhan Kitabevi.

Davis, J. (1980). Fiscal Marksmanship in the United Kingdom, 1951-78. The Manchester School, 187-202.

Edizdoğan, N. (1989). Kamu Bütçesi. Bursa: Uludağ Üniversitesi Basımevi.

Edizdoğan, N., \& Çetinkaya, Ö. (2010). Kamu Bütçesi. Bursa: Ekin Basım Yayın Dağıtım.

Enders, W. (2010). Applied Econometric Time Series. Hoboken, New Jersey: John Wiley \& Sons Inc.

Froyen, R. T. (2008). Macroeconomics Theories and Policies (Ninth Edition). Pearson International Edition.

Günlük Şenesen, G. (2000). Bütçe Başlangıç Ödeneklerinin Başarımının Değerlendirilmesinde Nicel Yaklaşımlar. 15. Türkiye Maliye Sempozyumu, 345-376. 
Gürsoy, B. (1980). Kamusal Maliye. Ankara: Ankara Üniversitesi Siyasal Bilgiler Fakültesi Yayınları No:436.

Lovell, M. C. (1986). Tests of The Rational Expectations Hypothesis. The American Economic Review, Vol. 76, No. 1, 110-124.

Morrison, R. (1986). Fiscal Marksmanshipin the United States: 1950-83. Manchester School of Economic and Social Studies, 322-333.

Muth, J. F. (1961). Rational Expectations and the Theory of Price Movemants. Econometrica, Vol. 29, No. 3, 315-335.

Rodgers, R., \& Joyce, P. (1996). The Effect of Underforecasting on The Accuracy of Revenue Forecast by State Governments. Public Administration Review, Vol. 56, No. 1, 48-56.

Sevüktekin, M., \& Çınar, M. (2014). Ekonometrik Zaman Serileri Analizi. Bursa: Dora Basım Yayın.

Theil, H. (1965). Economic Forecasts and Policy. Amsterdam: North-Holland Publishing Company.

Theil, H. (1971). Applied Economic Forecasting. Amsterdam: North-Holland Publishing Company.

Yılmaz, H. H. (2003). Konsolide Bütçe Gelir ve Gider Tahminlerinin Gerçekleşmelere Göre Güvenilirlik Düzeyi.

Zakaria, M., \& Ali, S. (2010). Fiscal Marksmanship in Pakistan. The Lahore Journal of Economics, Vol. 15, No. 2, 113-133. 